\title{
PROBLEM-SOLVING ABILITY OF STUDENTS WITH DISCIPLINARY LITERACY INSTRUCTION
}

M.Pd. Zulfah, Graduate School, Yogyakarta State University, Yogyakarta, Indonesia

E-mail: Zulfahzuu@gmail.com

Dr. rer. nat. Senam, Yogyakarta State University, Yogyakarta, Indonesia

Email: Senam@uny.ac.id

\section{A R T I C L E I N F O}

Original Research

Received: March, 12.2018 .

Revised: May, 30.2018.

Accepted: June, 27.2018.

doi:10.5937/ijcrsee1802081S

UDK

378.147.15:167.1

165.194

Keywords:

Disciplinary literacy instruction, problem-solving ability, cognitive learning outcomes, effect.

\begin{abstract}
A B S T R A C T
The literacy movement has not been widely applied to the learning. This study aims to determine the effect of the application of disciplinary literacy instruction to cognitive learning outcomes, especially in problem-solving ability. The population of this study is all senior high school in Sleman, Indonesia and have implemented the literacy movement in habituation and development. Two classes in SMAN 2 Sleman becomes sample with experimental and comparative classes. Both classes performed daily tests on two consecu-tive materials to see the abilities in the two classes. The results were analyzed using SPSS program and showed normal and homogeneous results and sig-nificance values were above of 0.05 were 0.968 and 0.483 respectively. This indicates that there is no difference in the cognitive learning outcomes of the two classes. The research instruments consist of the syllabus, learning implementation plan, article, student worksheet, and questions. Validation used in the form of content validation to two experts and empirical validation to 150 students. The analytical technique used to analyze the influence of the application of disciplinary literacy instruction on problem-solving ability is ANOVA test at significance level 0.05 . The results showed that both classes had normal and homogenous learning outcomes and significance value of 0.009 , the value is below the level of significance 0.05 . This number indicates that there is the influence of application of disciplinary literacy instruction on problemsolving ability in the electrolyte and non-electrolyte solutions material.
\end{abstract}

(C) 2018 IJCRSEE. All rights reserved.

\section{INTRODUCTION}

The implementation of school literacy movement at the high school level is conducted through three stages: (1) the stage of habituation, (2) the stage of development, and (3) the learning phase. Habituation phase can be implemented with growing interest in reading through 15 minutes of reading. The development phase is the next stage in order to improve the literacy skills through enrichment activities respond to the book. Phase habituation and development is the foundation to the last stage, the stage of learning. In this

Corresponding Author

M.Pd. Zulfah, Graduate School, Yogyakarta State

University, Yogyakarta, Indonesia

E-mail: Zulfahzuu@gmail.com

\section{cc) (i) $\ominus$}

This work is licensed under a Creative Commons Attribution - NonCommercial - NoDerivs 4.0. The article is published with Open Access at www.ijcrsee.com phase, the strategies used in teaching literacy in all subjects (General Directorate of Primary and Secondary Education, 2016: 8). In fact, literacy movements in some schools still at the stage of habituation and development. Systematic and continuous efforts need to be done to improve the literacy skills of students. School literacy movement to foster interest in reading and proficiency literacy has been implemented in Indonesia since 2016, but there is currently too touching aspects of learning in the classroom.

Chemistry as a product in the form of facts, concepts, principles, laws, and theories while the chemical as a form of scientific work processes and chemicals as attitude. Chemistry as a process and attitude can train problem-solving ability. Their scientific literacy in students will make students able to master science, with life skills and abilities in the face of scientific problems that arise in life. Problemsolving ability must also be owned by every student. Problem-solving ability skills can be trained in teaching chemistry, which is shown 
by the understanding the problem in reading and prepares according to the rules of scientific writing. In an article from Pelger and Nilsson said that the influence of the scientific literature students enormously in understanding the material (Pelger and Nilsson, 2016: 441). The learning process should train chemistry literacy with troubleshooting and write appropriate scientific principles. In fact, the learning process is still focused on the chemical aspects of the results. The learning process chemicals tend to encourage students to be able to work on the final exam only, while aspects of the process and a lack of attention. Conventional learning process which is still dominated by the lecture from the teacher.

Risnawati stated that the ability is the proficiency to perform a particular task within a predetermined condition (Risnawati, 2008: $24)$. In the learning process of acquisition is the purpose of learning ability. The ability is the capability that has been described specifically and stated in terms of behavior. According to Kennedy et.al (2007: 115), A problem is a situation that has no immediate solution or known solution strategy. Troubleshooting is a strategic competence shown students in understanding, selecting the model and coping strategies, and complete the model to solve the problem (BSNP, 2006: 59).

The points where they commonly get stuck while solving problem is dead ends that could result from (a) following a mis-conception or an alternative conception; (b) making inappropriate assumptions; (c) ignoring dimensional aspects of a problem; and (d) reporting an incorrect answer (Yuriev et al., 2017: 7). In talking through the problems, students take on regulative and instructional tasks, articulate problem-solving skills, ask and answer questions, and reflect on their learning. The student regulative communication helps the groups move through the problems by managing the group learning process, promoting discussion, restating or summarizing ideas, and confirming or questioning one another's contributions. The instructional communication show evidence of students actively practicing science language as they communicate with one another to move through and build content knowledge (Repice et al., 2016: 16).

According to Polya (1985), the problem of the problem contains 4 steps of completion, (a) to understand the problem that students can understand the problem so that students can determine the solution, (b) make the student's plan. (c) do the calculation of the students are ready to do the calculations in accordance with the plans that have been made, and (d) to re-check the results of students re-check every stage that has been done.

Problem-solving is one type of intellectual skill that is according to Gagne et al. (1992) is higher level and more complex than type other intellectual skills. Gagne et al. (1992) have argued that within solving the problem is required for complex rules or rules high level and high-level rules can be achieved by mastering the rules and defined concepts. Likewise, defined rules and concepts can be mastered if supported by understanding concrete concepts. After that to understand concrete concepts needed skills in differentiating. The intellectual skills are classified as Gagne based on levels its complexity and composed of the simplest mental operations up at the most complex level.

According to Jacobsen et.al (2009: 250) solving the problem has two goals: the shortterm goal is that the students were able to solve the problem and be able to understand the content is behind the problem. Besides the long-term goal is to make students understand the process of problem-solving and develop as Self-directed learning (students organize and control their own learning). When getting with the task of solving the problem in the absence of prior knowledge of relevant, so that students need to seek out parts that might be a solution to use problem-solving strategies (as opposed to a strategy based on a strong knowledge, domain) as a meaningful analysis or technique of trial and error, such activities can lead to a high cognitive load. One of the consequences of approaching the complex learning is the need to abandon the rigid dichotomy explicit teaching of learning that supports a flexible approach that takes into account the specific objectives of the various activities of students constituent (Likourezos and Kalyuga, 2017).

Bell (1978) has stated the results of the research indicate that strategy problem solving commonly studied in lessons, in some cases, can be transferred and applied within other problem-solving situations. Therefore the ability of student in solving a problem must continue to be sharpened. Because by solving problems students will find new concepts in learning.

Attempts to improve the learning process through the efforts of the selection of appropriate learning strategies and innovative in teaching chemistry in schools is a very important requirement to do. During this time teachers still tend to use expository teaching strategy, where most of the teaching and learn- 
ing activities are still dominated by teachers who actively teach chemistry, and provides examples and exercises, on the other hand, the students just listen, take notes, and work on the problems provided by the teacher. These conditions are not going to develop aspects of personality, ability, and the student activity as expected. Because it requires a learning strategy that involves students who proceed to troubleshoot so that students will understand, appreciate, and take lessons from his experience. The purpose of this study is to determine whether or not the implementation effect of learning strategy with disciplinary literacy instruction to the ability to solve problems on the material of electrolyte and non-electrolyte solution in the tenth grade of senior high school.

\section{MATERIALS AND METHODS}

This study uses a quasi-experimental with posttest only group design. In an experimental and comparative class applied learning strategies, the experimental class using strategy with disciplinary literacy instruction and another class applied comparative study by using the usual expository strategy in the classroom.

Table 1. Research Design

\begin{tabular}{cccc}
\hline No & Class & Treatment & Posttest \\
\hline 1 & A & X & O \\
\hline 2 & B & Y & O \\
\hline \multicolumn{4}{c}{ Description: } \\
A: Experimental Class \\
B: Comparative Class \\
X: Learning strategy with disciplinary \\
literacy instructions \\
Y: Learning strategy with expository \\
O: Test of problem-solving ability
\end{tabular}

The population of the study is the state senior high schools located in the districts of Sleman and have implemented literacy at the stage of habituation and development. Some state senior high school were interviewed and observed about the implementation of literacy in learning and the results of which have the same characteristics that have not been fully implemented literacy in a learning phase. The sample used in the study of a randomly selected school that was selected SMAN 2 Sleman as a research site. Two classes are used for the purposes of this study are XMIA 1 as the experimental class and XMIA 2 as the comparative class.
The independent variable in this study is a learning strategy with disciplinary literacy instruction while the control variable is the problem-solving ability of the material of electrolyte and nonelectrolyte solution. Data collected by the data nontest and test. Mechanical nontest data collection is done by observation and interview. The observations were made with the observation sheet to observe the learning process in accordance with the lesson plan using strategies disciplinary literacy instruction for experimental class and expository strategy for comparative class.

Disciplinary literacy instruction represents a paradigm shift in content area literacy pedagogy, requiring LTEs to re-envision and redesign their course in ways that support students' acquisition of disciplinary content and habits of mind (Fang, 2014: 447). Along with the challenges of disciplinary literacy, there are also possibilities, which can be exciting for teachers. The instructional procedures that have proven successful in students' literacy development are based on engagement with the text, and the practices and strategies for disciplinary literacy build on this work (Fanna, 2015). Professional development is critical if disciplinary literacy practices are going to deepen what it means to read in each academic subject area. The focus of disciplinary literacy is how literacy is used to make meaning within and discipline and the role of graphics is specific to the discipline (Shanahan, 2015: 15). Given the modifications we made, is a reasonable and potentially useful one for promoting disciplinary literacy in social studies among middle-school students and among pre-service social studies teachers (Colwell, 2013:12).

Tests are a number of questions that must be addressed with the aim of measuring the level of a person's ability or reveal certain aspects of a person subjected to the tests. In this study, tests were conducted to measure the ability to solve problems by using the description matter. Set about the description made as many as 15 items, grating matter and guidelines for assessment and validation process is carried out. The validity of research instruments carried into two parts, namely the validity of the theoretical and empirical validity. The validity of theoretically calculated with the Aiken formula (Aiken, 1985). In addition to the validity, data collection instruments should also be ensured that the measurement results remain consistent (reliable). In this study the reliability test using Quest program. Test of the hypothesis analysis was used ANO- 
VA with SPSS 22. Before analyzing the data, the data is tested for normality and homogeneity of variance. Anova is done by looking at the hypothesis criteria are:

Ho: No effect of the application of learning strategy with disciplinary literacy instruction to the ability to solve problems on the material of electrolyte and non-electrolyte solution in the tenth grade of senior high school.

Ha: There is an effect of the application of learning strategy with disciplinary literacy instruction to the ability to solve problems on the material of electrolyte and non-electrolyte solution in the tenth grade of senior high school.

\section{RESULTS}

The study began by conducting interviews with several senior high schools in Sleman country and interview show that the literacy learning is still rarely performed. Then the technique of sampling with random sampling and set SMAN 2 Sleman as a research site. At the school were taken two classes, one class as the experimental class and the other class designated as the comparative class.

Learning to use disciplinary literacy instruction aided by using articles that have been made and validated it. Some of the articles used in this study on the implementation of the material an electrolyte and non-electrolyte solutions in life. A set of instruments such as the questionnaire, syllabus, lesson plan and observation sheet of lesson plans, articles and worksheets for students and validated descriptions about the contents on two experts and conducted empirical validation and reliability seen at 150 students. The student who is the subject of the implementation of the validation is the eleventh-grade students who already have material electrolyte and non-electrolyte solutions. The results of the validation and reliability are then processed with the help of the program Quest and obtained the results as shown in Figure 1:

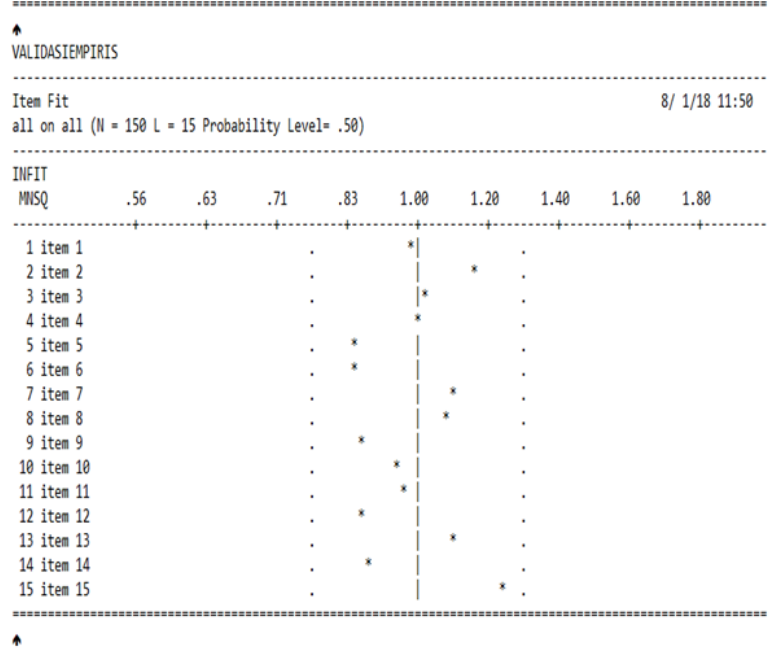

Figure 1. Results Quest analysis of empirical validation

Based on Figure 1 shows that all the stars items about shows in the brackets, then by using the calculation of the Aiken formula, the instrument of this matter is valid. Reliability is analyzed by using Quest program and produce reliable data with value Cronbach's alpha 0.73. However, the implementation of data collection is only 10 questions were needed and used to test students. Two classes used in this study extend the initial assumption of equality of cognitive abilities through daily tests in the previous chapter. The analysis was performed using one way ANOVA analysis with the SPSS.22 program. Before the ANOVA test analysis, the data were tested for normality and homogeneity and show normal and homogeneous data. Results of ANOVA analysis on the first previous chapter can be seen in Table 2:

Table 2. One-way ANOVA test result of first material

\begin{tabular}{cccccc}
\hline & $\begin{array}{c}\text { Sum of } \\
\text { Squares }\end{array}$ & df & $\begin{array}{c}\text { Mean } \\
\text { Square }\end{array}$ & F & Sig \\
\hline $\begin{array}{c}\text { Between } \\
\text { groups }\end{array}$ & .063 & 1 & .063 & .002 & .968 \\
\hline $\begin{array}{l}\text { Within } \\
\text { Groups }\end{array}$ & 2356.375 & 62 & 38.006 & & \\
\hline Total & 2356.438 & 63 & & & \\
\hline
\end{tabular}

Table 2 shows the value of signifi-cance is greater than 0.05 , namely 0.968 . Then to get more accurate data that both classes have the same ability then analyzed in the second test of the previous chapter. As the first daily test analysis, the data were tested for normality 
and homogeneity using SPSS 22 and then proceed ANOVA analysis of one way. Results of ANOVA analysis on second previous chapter can be seen in Table 3:

Table 3. One-way ANOVA test result of second material

\begin{tabular}{cccccc}
\hline & $\begin{array}{c}\text { Sum of } \\
\text { Squares }\end{array}$ & df & $\begin{array}{c}\text { Mean } \\
\text { Square }\end{array}$ & F & Sig \\
\hline $\begin{array}{c}\text { Between } \\
\text { groups }\end{array}$ & 20.816 & 1 & 20.816 & .498 & .483 \\
\hline $\begin{array}{c}\text { Within } \\
\text { Groups }\end{array}$ & 2590.930 & 62 & 41.789 & & \\
\hline Total & 2611.746 & 63 & & & \\
\hline
\end{tabular}

Table 3 shows the value of signifi-cance is greater than 0.05 , namely 0.483 . Both daily tests performed showed signifi-cance above 0.05 which indicates that both classes have the same ability in cognitive learning outcomes. Then the research was done by providing the treatment in the experimental class. The study was conducted during the four meetings with the four stages of learning and one posttest data retrieval. Each meeting in the learning phase students read the article, understand and discuss together in the classroom, guided by the subject teachers. Then at the fourth meeting of the two classes doing the practice by observing various electrolyte and non-electrolyte solutions, it was assisted by students worksheet to train students ability to solve problems. After the posttest and the got the average value of the two classes as shown in Figure 2:

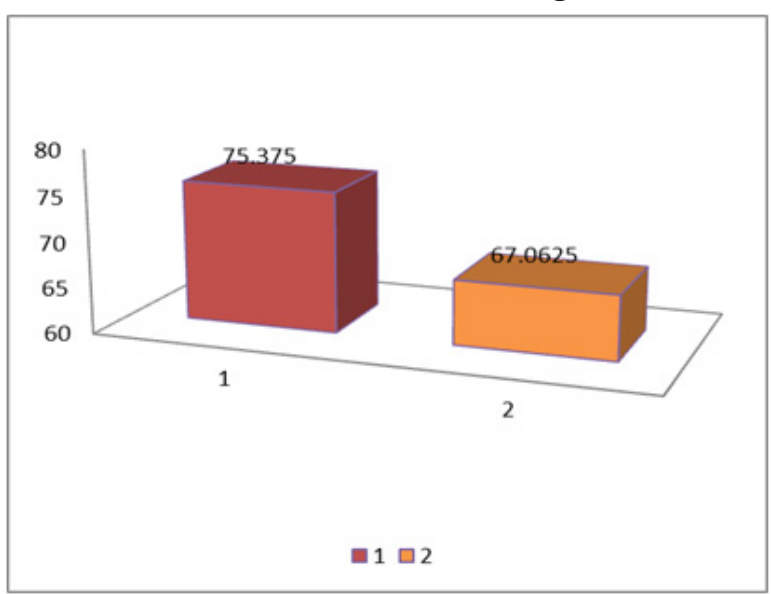
classes

Figure 2. Average value of the two

Description:

1: Average of experimental class

2: Average of comparative class
The diagrams show significant differences in students' cognitive ability outcomes, especially problem-solving skills in the experimental and comparative classes. Not only see the average value but also see significant value through ANOVA analysis. The results of the data problem-solving ability of students showed homogeneous and normal data as shown in Table 4:

Table 4. Results of the test of normality test problem-solving ability

One-Sample Kolmogorov-Smirnov Test

\begin{tabular}{llrr}
\hline & & Test & Class \\
\hline $\mathrm{N}$ & & 64 & 64 \\
\hline Normal & Mean & 71.22 & 1.50 \\
\cline { 2 - 4 } Parametersa, & Std.Deviation & 12899 & .504 \\
\hline Most Extreme & Absolute & .113 & .339 \\
\cline { 2 - 4 } \begin{tabular}{l} 
Differences \\
\cline { 2 - 4 }
\end{tabular} & Positive & .113 & .339 \\
\cline { 2 - 4 } & Negative & -.080 & -.339 \\
\hline Test Statistic & & .113 & .339 \\
\hline Asymp. Sig. (2-tailed) & $.041^{\mathrm{c}}$ & $.000^{\mathrm{c}}$ \\
\hline
\end{tabular}

a. Test distribution is Normal.

b. Calculated from data.

c. Significance Lilliefors Correction.

Table 5. Results of homogeneity test problem-solving ability

\begin{tabular}{cccc}
\hline Levene Statistic & DF1 & DF2 & Sig. \\
\hline 1275 & 1 & 62 & .263 \\
\hline
\end{tabular}

On the Table $4 \& 5$ indicate that the data is normal and homogeneous, so the data analysis can be continued by using one way ANOVA analysis to see the effect of the treatment given. The results of data analysis can be seen in Table 6:

Table 6. One-way ANOVA test result of the problem-solving ability

\begin{tabular}{cccccc}
\hline & $\begin{array}{c}\text { Sum of } \\
\text { Squares }\end{array}$ & df & $\begin{array}{c}\text { Mean } \\
\text { Square }\end{array}$ & F & Sig \\
\hline $\begin{array}{c}\text { Between } \\
\text { groups }\end{array}$ & 1105.563 & 1 & 1105.563 & 7.310 .009 \\
\hline $\begin{array}{c}\text { Within } \\
\text { Groups }\end{array}$ & 9377.375 & 62 & 38.006 & \\
\hline Total & 10482.938 & 63 & & \\
\hline
\end{tabular}




\section{DISCUSSIONS}

In the 21 st century, people are required to master literacy such as reading and writing literacy, science literacy, information and communication technology literacy, financial literacy, and cultural and civic literacy. Literacy has become a familiar term for many, but not many of them understand it well. Literacy can be fundamentally defined as a person's ability to process and understand information while doing the process of reading and writing. Literacy requires a range of cognitive abilities, written and spoken language knowledge, knowledge of genres and cultures. School as a portrait of the miniature society that can form the character of the student as a literate individual. Therefore, the school can be a place to cultivate good literacy at the stage of habituation, development, and learning, and until now the literacy at the stage of splinting has not been widely applied. Disciplinary literacy is learning strategy by finding concepts, principles of learning and training students to compile and transform information.

In the study, two consecutive chapters show data from two classes are normal and homogeneous, then seen the differences, and show no difference in terms of cognitive ability. It became the material and reference for continuing research on the influence strategy of disciplinary literacy instruction.

In the experimental study, the experimental class is given treatment by disciplining the literacy on the learning while in the comparative class is applied expository learning strategy where expository learning is a traditional learning that has been passed down in the class. Expository learning is centered on the teacher so that the teacher as the main informant. The implementation of learning strategy of disciplinary literacy instruction is expected to influence the ability to solve the problems of the students.

In this study will see the effect of strategy on the condition of students' cognitive abilities the same to the problem-solving ability. All types of literacy, literacy is preferred in this study. The teacher has prepared several articles as a supporting material for every learning that takes place. This disciplinary instruction has several advantages to discipline literacy especially in terms of literacy reading such as helping students understand the concept.

The first lesson in the experimental class begins with giving an article about the battery and its relation to the electrolyte and non- electrolyte solutions material. The discussion of this literacy understands and discusses how electrolyte solutions are placed in containers or battery vessels made of ebonite or glass materials. Both plates are made of lead $(\mathrm{Pb})$, and when first loaded there will be a layer of lead dioxide $(\mathrm{PbO} 2)$ on the positive plate. Positive and negative plates are very close together but are made to not touch each other in the presence of a separator layer that serves as an insulator (insulating material). Chemical processes that occur in the battery can be divided into two important parts, namely during use and re-loaded or electrocuted. In this case, the educator tries to facilitate the student to discuss both processes.

At the second meeting, the teacher gave an article about isotonic in the body which is certainly related to the material of electrolyte and non-electrolyte solution. For example, isotonic drinks are used as a substitute for lost body fluids because they have a similar composition to body fluids such as electrolytes and the composition is designed with the same osmotic pressure as the blood pressure in the body.

At the next meeting, the article contains about a drug called oralit in it also contains electrolyte salt. The body must be able to maintain the concentration of all the appropriate electrolytes in the body fluids, it makes easy to achieve fluid and electrolyte balance. The article also contains a description of how oralit can balance electrolyte fluid levels in the body in conditions such as excessive sweating, vomiting, or diarrheal disease. In each article students are required to understand the reading holistically and search for important sentences about the concept of matter. In addition, students are brought on real-life related to chemistry.

At the last meeting, the two classes were given a problem that had to be solved by the practice process and then followed by a meeting that tested the problem-solving ability with the description problems and saw at how is the difference of two classes. Both test results not only show different mean values but when tested using ANOVA program shows the significance value of 0.009 , the value is below the level of significance 0.05 , which indicates that there is a significant effect of the implementation of learning strategy with disciplinary literacy instruction on problem-solving ability in the electrolyte and non-electrolyte solutions material. If a student has been practicing solve the problem, then in real life, the student will be able to take a decision on an 
issue, because they have the skills to collect relevant information, analyze information, and realize how necessary to re-examine the results already obtained. The problem-solving ability can be seen as one of the process and result of instructions.

\section{CONCLUSIONS}

This research concludes that the implementation of learning strategy with disciplinary literacy instruction influence the students' ability to solve problems in the material of electrolyte and non-electrolyte solutions material in tenth grade at senior high school.

\section{ACKNOWLEDGMENTS}

We would like to express our institution, Yogyakarta State University that has provided many experiences in term of research. Our deepest gratitude to all student who participated in our experiment research and also who have contributed to the collection of empirical data. Thankfully to the principal and teacher of senior high school who helped this research in terms of coordination.

\section{Conflict of interests}

The authors declare no conflict of interest.

\section{REFERENCES}

Aiken, L.R. (1985). Three coefficients for analyzing the reliability and validity of ratings. Educational and Psychological Measurement, 45, 131-142. https://doi.org/10.1177/0013164485451012

Bell, F. H. (1978). Teaching and learning mathematics (in secondary schools). WC Brown Company.

BSNP. (2006). Research Model Class. Jakarta: Ministry of Education.

Colwell, J., \& Reinking, D. (2013). Integrating disciplinary literacy into middle-school and preservice teacher education. Educational design research-Part B: Illustrative cases, 469-480. http://international.slo.nl/bestanden/Ch23.pdf/

Fang, Z. (2014). Preparing content area teachers for disciplinary literacy instruction: The role of literacy teacher educators. Journal of Adolescent \& Adult Literacy, 57(6), 444-448. https://doi. org/10.1002/jaal.269

Fanna, C. (2015). Cipl Professional Learning Series: An Educator's Guide to Disciplinary Literacy. NYC Department of Education: New York.

Gagne, R. M., Briggs, L. J dan Wager, W. W (1992). Principles of Instructional Design (4nd ed). Orlando: Holt, Rinehart and Winstone, Inc.

General Directorate of Primary and Secondary Education. (2017). General Material Literacy in learning. Jakarta: Ministry of Education and Culture.
Jacobsen, D. A., Eggen, P., \& Kauchak, D. (2009). Methods for Teaching (Achmad Fawaid dan Khoirul Anam. Terjemahan). $8^{\text {th }}$. Yogyakarta: Pustaka Pelajar.

Kennedy, L., Tipps, S., \& Johnson, A. (2007). Guiding children's learning of mathematics. Cengage Learning.

Likourezos, V., \& Kalyuga, S. (2017). Instruction-first and problem-solving-first approaches: alternative pathways to learning complex tasks. Instructional Science, 45(2), 195-219. https://doi. org/10.1007/s11251-016-9399-4

Pelger, S., \& Nilsson, P. (2016). Popular science writing to support students' learning of science and scientific literacy. Research in Science Education, 46(3), 439-456. https://doi.org/10.1007/s11165015-9465-y

Polya, G. (1985). How To Solve It $2^{\text {nd }}$ ed. New Jersey: Princeton University Press.

Repice, M. D., Sawyer, R. K., Hogrebe, M. C., Brown, P. L., Luesse, S. B., Gealy, D. J., \& Frey, R. F. (2016). Talking through the problems: a study of discourse in peer-led small groups. Chemistry Education Research and Practice, 17(3), 555568. https://doi.org/10.1039/c5rp00154d

Risnawati. (2008). Math Learning Strategies. Pekanbaru: Suska Press.

Shanahan, C. (2015). Disciplinary literacy strategies in content area classes. ILA E-Ssentials, 1-18. https://education.ucf.edu/mirc/docs/Disciplinary-literacy-strategies-in-content-area-classes2015.pdf

Yuriev, E., Naidu, S., Schembri, L. S., \& Short, J. L. (2017). Scaffolding the development of problem-solving skills in chemistry: guiding novice students out of dead ends and false starts. Chemistry Education Research and Practice, 18(3), 486-504. https://doi.org/10.1039/C7RP00009J 